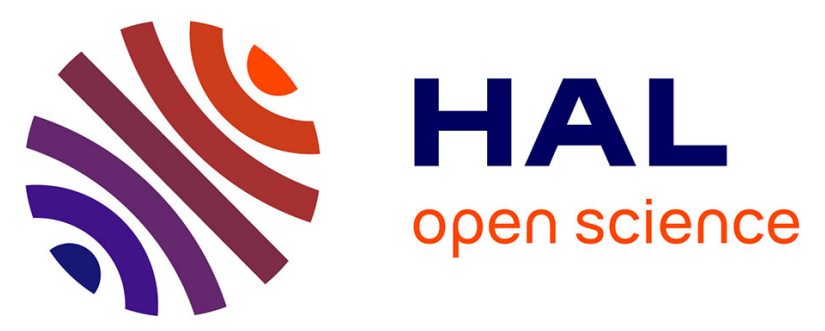

\title{
Assessment of PCDD/F, PCB, OCP and BPA dietary exposure of non-breast-fed European infants
}

\author{
Marchela Pandelova, Raffaela Piccinelli, Walkiria Levy Lopez, Bernhard \\ Henkelmann, Jose Manuel Molina-Molina, Juan Pedro Arrebola, Nicolas Olea, \\ Catherine Leclercq, Karl-Werner Schramm
}

\section{To cite this version:}

Marchela Pandelova, Raffaela Piccinelli, Walkiria Levy Lopez, Bernhard Henkelmann, Jose Manuel Molina-Molina, et al.. Assessment of PCDD/F, PCB, OCP and BPA dietary exposure of non-breastfed European infants. Food Additives and Contaminants, 2011, pp.1. 10.1080/19440049.2011.583281 . hal-00712358

\section{HAL Id: hal-00712358 https://hal.science/hal-00712358}

Submitted on 27 Jun 2012

HAL is a multi-disciplinary open access archive for the deposit and dissemination of scientific research documents, whether they are published or not. The documents may come from teaching and research institutions in France or abroad, or from public or private research centers.
L'archive ouverte pluridisciplinaire HAL, est destinée au dépôt et à la diffusion de documents scientifiques de niveau recherche, publiés ou non, émanant des établissements d'enseignement et de recherche français ou étrangers, des laboratoires publics ou privés. 


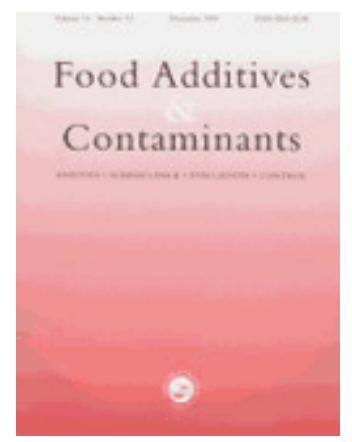

\section{Assessment of PCDD/F, PCB, OCP and BPA dietary exposure of non-breast-fed European infants}

\begin{tabular}{|c|c|}
\hline Journal: & Food Additives and Contaminants \\
\hline Manuscript ID: & TFAC-2011-029.R1 \\
\hline Manuscript Type: & Original Research Paper \\
\hline $\begin{array}{r}\text { Date Submitted by the } \\
\text { Author: }\end{array}$ & 14-Apr-2011 \\
\hline Complete List of Authors: & $\begin{array}{l}\text { Pandelova, Marchela; Helmholtz Zentrum München, Institute of } \\
\text { Ecological Chemistry } \\
\text { Piccinelli, Raffaela; National Research Institute on Food and } \\
\text { Nutrition } \\
\text { Levy Lopez, Walkiria; Helmholtz Zentrum München, Institute of } \\
\text { Ecological Chemistry } \\
\text { Henkelmann, Bernhard; Helmholtz Zentrum München, Institute of } \\
\text { Ecological Chemistry } \\
\text { molina-molina, jose manuel; university of granada, hospital clinico } \\
\text { Arrebola, Juan Pedro; university of granada, hospital clinico } \\
\text { olea, nicolas; university of granada, hospital clinico; CIBER in } \\
\text { Epidemiology and Public Health } \\
\text { Leclercq, Catherine; National Research Institute on Food and } \\
\text { Nutrition } \\
\text { Schramm, Karl-Werner; Helmholtz Zentrum München, Institute of } \\
\text { Ecological Chemistry }\end{array}$ \\
\hline Methods/Techniques: & $\begin{array}{l}\text { Bioassay, Chromatography - GC/MS, Chromatography - LC/MS, } \\
\text { Exposure assessment }\end{array}$ \\
\hline Additives/Contaminants: & Bis-phenol A, Dioxins, PCBs, Pesticides - organochlorine \\
\hline Food Types: & Baby food, Beverages, Infant formulae \\
\hline Abstract: & $\begin{array}{l}\text { The aim of the study was to obtain data on the exposure of non- } \\
\text { breast-fed infants to polychlorinated dibenzo-p-dioxins and } \\
\text { dibenzofurans (PCDD/F), polychlorinated biphenyls (PCB), } \\
\text { organochlorine pesticides (OCP), and Bisphenol A (BPA) and its } \\
\text { chlorinated derivatives through consumption of commercial infant }\end{array}$ \\
\hline
\end{tabular}




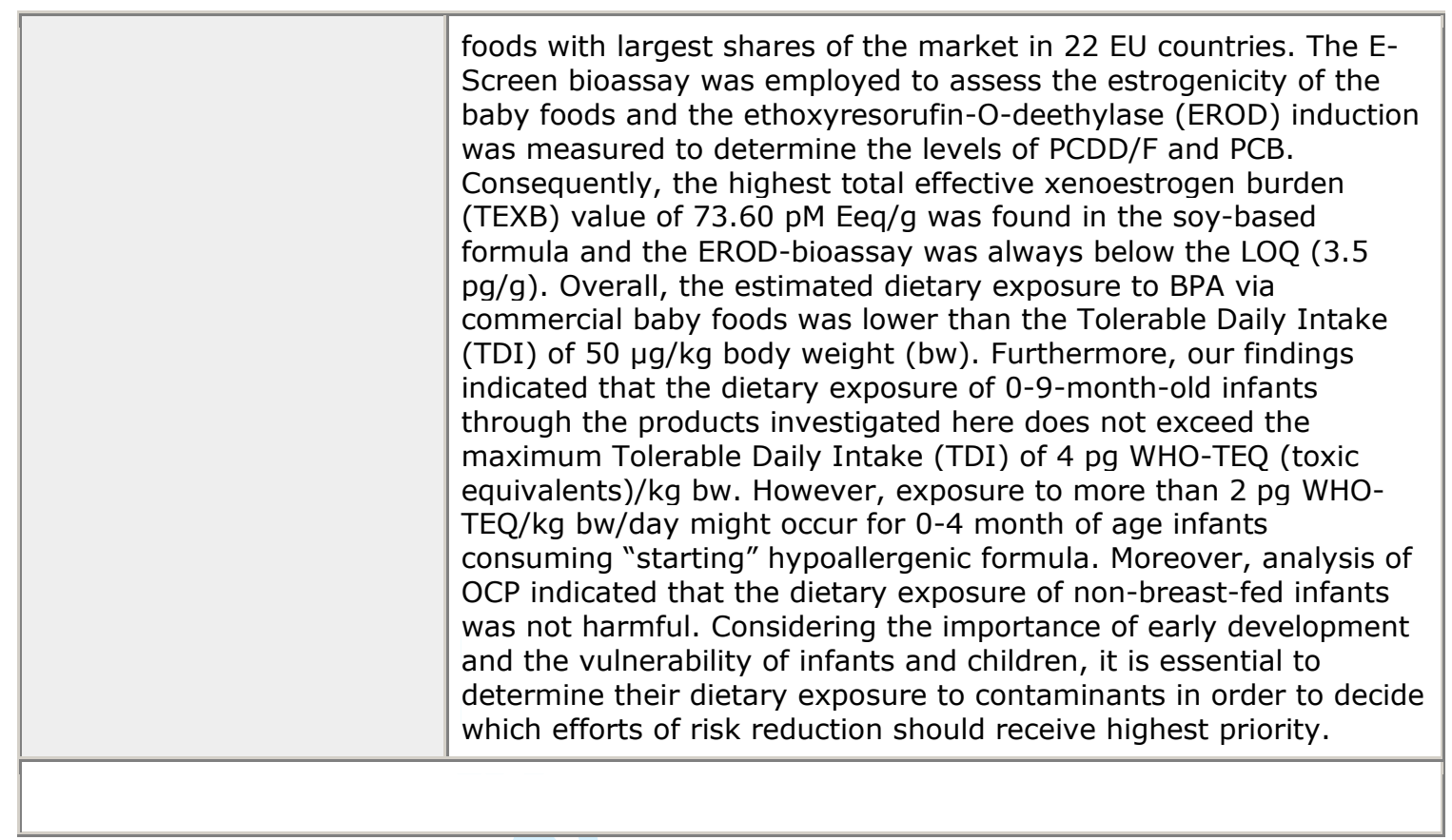

\section{SCHOLARONE"} Manuscripts 
1 Assessment of PCDD/F, PCB, OCP and BPA dietary exposure of non2 breast-fed European infants

3

M. Pandelova ${ }^{\text {a, }}{ }^{1}$, R. Piccinelli ${ }^{\text {b }}$, W. Levy Lopez ${ }^{\text {a }}$, B. Henkelmann ${ }^{\text {a }}$, J.M. Molina-Molina ${ }^{\text {c,d }}$, J.P. Arrebola $^{c, d}$, N Olea. ${ }^{c, d}$, C. Leclercq ${ }^{\text {b }}$ K.-W. Schramm ${ }^{\text {a,e }}$

${ }^{a}$ Helmholtz Zentrum München, German Research Center for Environmental Health, Institute of Ecological Chemistry, Ingolstädter Landstrasse 1, 85764 Neuherberg, Germany

${ }^{b}$ National Research Institute on Food and Nutrition, Rome, Italy

${ }^{c}$ Laboratory of Medical Investigations, San Cecilio University Hospital, University of Granada, Granada, E-18071, Spain

${ }^{d}$ CIBER in Epidemiology and Public Health (CIBERESP), Granada, E-18071, Spain

e TUM, Wissenschaftszentrum Weihenstephan für Ernährung und Landnutzung, Department für Biowissenschaften, Weihenstephaner Steig 23, 85350 Freising, Germany

Received date:

Final version received date

\section{Abstract}

The aim of the study was to obtain data on the exposure of non-breast-fed infants to polychlorinated dibenzo-p-dioxins and dibenzofurans (PCDD/F), polychlorinated biphenyls (PCB), organochlorine pesticides (OCP), and Bisphenol A (BPA) and its chlorinated derivatives through consumption of commercial infant foods with largest shares of the market in 22 EU countries. The E-Screen bioassay was employed to assess the estrogenicity of the baby foods and the ethoxyresorufin-O-deethylase (EROD) induction was measured to determine the levels of PCDD/F and PCB. Consequently, the highest total effective xenoestrogen burden (TEXB) value of $73.60 \mathrm{pM} \mathrm{Eeq/g}$ was found in the soybased formula and the EROD-bioassay was always below the LOQ (3.5 pg/g). Overall, the estimated dietary exposure to BPA via commercial baby foods was lower than the Tolerable Daily Intake (TDI) of $50 \mu \mathrm{g} / \mathrm{kg}$ body weight (bw). Furthermore, our findings indicated that the dietary exposure of 0-9month-old infants through the products investigated here does not exceed the maximum Tolerable Daily Intake (TDI) of 4 pg WHO-TEQ (toxic equivalents)/kg bw. However, exposure to more than 2 pg WHO-TEQ/kg bw/day might occur for 0-4 month of age infants consuming "starting" hypoallergenic formula. Moreover, analysis of OCP indicated that the dietary exposure of non-breast-

\footnotetext{
1 * Corresponding author: Marchela Pandelova, Helmholtz Zentrum München, Neuherberg, Germany E-mail: pandelova@helmholtz-muenchen.de
} 
fed infants was not harmful. Considering the importance of early development and the vulnerability of infants and children, it is essential to determine their dietary exposure to contaminants in order to decide which efforts of risk reduction should receive highest priority.

Keywords: PCDD/F; PCB; OCP; BPA; food; infant

\section{Introduction}

42 Food is generally recognized as the main source of human exposure to persistent organic pollutants 43 (POPs) such as polychlorinated dibenzo- $p$-dioxins and dibenzofurans (PCDD/F), polychlorinated 44 biphenyls (PCB) and organochlorine pesticides (OCP) (Ahlborg et al., 1995; Weijs et al., 2006). 45 Several health risk assessments were used by different authorities to propose safety limits for all 46 human sub-population deriving from non-carcinogenic end-points and referring to different exposure 47 periods. A WHO-expert consultation in May 1998 ended with the establishment of a Tolerable Daily 48 Intake (TDI) of 1-4 pg WHO-TEQ (toxic equivalents)/kg body weight (bw) (WHO, 2000). In 2001, 49 the Scientific Committee on Food of the European Commission established a Tolerable Weekly Intake 50 (TWI) of $14 \mathrm{pg} \mathrm{TEQ} / \mathrm{kg}$ bw (SCF, 2001) for the European population. More, recently the Joint 51 FAO/WHO Expert Committee of Food Additives established a Provisional Tolerable Monthly Intake 52 (PTMI) of $70 \mathrm{pg}$ WHO-TEQ/kg bw/month (JECFA, 2002).

54 Children, particularly infants, can be biologically more sensitive to certain toxicant on the body weight 55 basis than adults. Current understanding of the rates of maturation of metabolism and evidence from case studies indicated that infants up to the age of 6 months typically lack the capacity to detoxify and eliminate substances as readily as adults (Dourson et al., 2004). Moreover, the Scientific Committee on Food of the European Commission stated that the estimated dioxin dietary exposure of breast-fed infants is one to two orders of magnitude higher than the estimated adult dietary exposure (SCF, 60 2001). Although there is considerable evidence that the concentrations of PCDD/F and OCP in breast 61 milk have fallen in recent years (Krauthacker et al., 2006; Mueller et al., 2008; Hsu et al., 2007). Since 62 breast-feeding has a measurable positive influence on neurological and immunological development, a 63 formula diet should not be recommended as a means of lowering dioxin intake. At the same time in 64 some EU countries only about $50 \%$ of mothers initiate breast-feeding (Cattaneo, 2008). According to statistics from 2007 few European women breastfeed their infants exclusively at six months of age (EC, 2004) and only $33.1 \%$ of infants in the USA are exclusively breastfed up to 3 months of age (CDC). The increasing number of mothers who feed their babies industrially processed formula milk 68 or solid foods as vegetables and meat or fish purée, has caused the baby market to grow significantly 69 and with it, the assortment of products offered. According to the DONALD study, the sale of 70 commercial infant food in Germany in 1996 was approximately $30 \%$ of the total sales of dietetic foods (Kersting et al., 1998). 
Thus, commercial infant food plays an important role in the infant's diet, but few studies have examined the PCDD/F, PCB and OCP in formula milk consumed by infant (Hsu et al., 2007; Lorán et al., 2007; Chovancová et al, 2005; Ramos et al., 1989; Weijs et al., 2006; Mezcua et al., 2007). Additionally, it has been shown that exposure to bisphenol A (BPA) occur through the consumption of beverages or foods that have been in contact with polycarbonate plastic containers or epoxy resins in food packaging (Kubwabo et al., 2009; Maragou et al., 2006; Lopez-Espinosa et al., 2007). BPA is readily chlorinated by reaction with residual chlorine molecules, e.g. residual chlorine used as a disinfectant in drinking water (Zafra et al., 2003) or sodium hypochlorite, which is usually applied as a bleaching agent in paper factories (Fukazawa et al., 2002). Therefore, chlorinated BPA derivatives are potential contributors to inadvertent human exposure to bisphenols. In fact, tetrachlorobisphenol-A and lower chlorinated analogues (mono-, di- and tri-chloroBPA) were recently detected in the environment (Liu et al. 2009) and human tissues (Fernandez et al., 2007). In addition, chlorinated BPA derivatives have been shown to be estrogenic (Rivas et al., 2001), with affinities for estrogen receptors that are sometimes higher than those of the parent BPA compound (Takemuraet al. 2005; Kitamura 2005). In its risk assessment on BPA adopted in 2006, the European Food Safety Authority (EFSA) set a Tolerable Daily Intake (TDI) of $50 \mu \mathrm{g} / \mathrm{kg}$ bw (EFSA, 2006) for this substance. EFSA re-confirmed the TDI in its 2010 opinion, while pointing out some uncertainties (EFSA, 2010). Successively, the European Commission has announced a ban on the use of BPA in plastic baby bottles from June 2011. The current study, as a part of the EU funded research project CASCADE (Chemicals as contaminants in the food chain; Network of Excellence, FP6 funded consortium, targeting health risks in food) is aimed at evaluating the current dietary exposure levels of non-breast-fed European infants. By the use of chemical target analysis, the scientific focus has in particular been on PCDD/F, PCB, OCP and BPA and some of its chlorinated derivatives. For this purpose, milk-, soy- and hypoallergenic-based infant formulae, as well as solid foods and beverages from the EU market were examined. Additionally, the E-Screen bioassay was used to assess the estrogenicity of the baby foods and the ethoxyresorufin-O-deethylase (EROD) induction was measured for determination of PCDD/F and PCB. Furthermore, the dietary exposure of non-breast-fed infants of age 0-9 months of age were estimated and compared with the above mentioned Tolerable Daily Intakes.

\section{Materials and Methods}

\section{Baby food samples included in the study}

Market baskets of baby foods designed for consumption during the first 9 months of life by an "average" EU baby fed with infant formulae and weaned (at the $5^{\text {th }}$ month) with solid foods and beverages were put together (Table 1). The subsequent investigations concerned an infant whose diet consisted entirely of commercial baby foods, i.e. who was not breast fed at all. The 2007 market data made available by "Food for Thought" (www.fft.com) was used to identify the major brands of baby foods and their shares of the market in $22 \mathrm{EU}$ countries considered to represent the entire EU. 
109 A total of 6 pooled samples of "starting" infant formulae of milk-based (Mf), soy-based (Sf), 110 hypoallergenic-based (HAf) and "follow-on" infant formulae of milk-based (fMf), soy-based (fSf) and 111 hypoallergenic-based (fHAf) and 5 pooled samples of solid foods and beverages (SFB) designed for 112 5-9-month-old infants (SFB5, SFB6, SFB7, SFB8, and SFB9) were prepared separately for chemical 113 target analysis. The proportion of each product in the pooled sample was the same as its share of the 114 European market. Further details have been reported elsewhere (Piccinelli et al., 2010). In order to 115 assess the potential exposure to nuclear receptor through the whole diet, another 6 pooled samples of $116 \mathrm{fMf}+\mathrm{SFB} 5, \mathrm{fMf}+\mathrm{SFB} 9, \mathrm{fSf}+\mathrm{SFB} 5, \mathrm{fSf}+\mathrm{SFB} 9, \mathrm{fHAf}+\mathrm{SFB} 5$, and $\mathrm{fHAf}+\mathrm{SFB} 9$ were further prepared.

117 (Table 1 here)

118

119 Lyophilisation was performed for baby jar and beverage products using freeze drying equipment 120 (Type BETA 1-16, Christ $\mathrm{GmbH}$ ) with duration of about $36 \mathrm{~h}$ per sample. Consequently the fresh 121 weight (fw) of $20 \mathrm{~g}$ solid foods and beverages for SFB5, SFB6, SFB7, SFB8, and SFB9 resulted dry 122 weight (dw) of 9.44, 8.55, 8.01, 8.59, $7.87 \mathrm{~g}$, respectively. The homogenisation of the pooled infant 123 formulae and solid food and beverages samples was done after the lyophilisation of the separate items.

124 The weighing procedures were performed in a purified glove box under nitrogen atmosphere and the 125 pooled samples were further homogenised in a rotoshaker (Type Reax 20/8, Heidolph GmbH) for 8 h. 126 The samples were kept at room temperature and stored in brown glass jars protected from direct light.

127 In order to prevent any contamination the opening and closing of the sample collector was performed 128 under nitrogen atmosphere.

129

130 Determination of PCDD/F and dioxin-like PCB amounts in baby food samples

131 Extraction of $20 \mathrm{~g}$ of fw infant formulae and $15 \mathrm{~g}$ of freeze dried solid foods and beverages was 132 carried out on Accelerated Solvent Extractor (ASE 200, Dionex GmbH, Idstein, Germany) using a 133 mixture of n-hexane: acetone (75:25, v/v) at $120^{\circ} \mathrm{C}$ and at a pressure of $12 \mathrm{MPa}$ (Cok et al., 2009). 134 Two static cycles of $10 \mathrm{~min}$ were applied for a complete extraction. Cleanup encompassed sandwich, 135 carbon and alumina chromatographic columns. PCB and PCDD/F analyses were performed by 136 HRGC/HRMS. Detail information on clean-up procedure and instrumental parameters are given 137 elsewhere (Cok et al., 2009). The tetra to octa PCDD/F and tetra to hepta PCB were identified and 138 reported in pg WHO-TEQ/g fw. The older WHO 1998 Toxic Equivalency Factors (TEFs) values were 139 used because all regulatory limits were still based on them. The lower and upper bounds approach was 140 applied for quantification of the results as described elsewhere (WHO, 2003). For lower bound (LB) 141 values, the concentration was set equal to zero if it was below the limit of quantification (LOQ). For 142 upper bound (UB) values, the concentration was set equal to the LOQ if it was below the LOQ. So the 143 UB values present the highest possible amount of a contaminant based on the analytical results. The 144 analytical laboratory involved is quality assured according to DIN EN ISO/IEC 17025 and accredited 145 for the analysis of PCDD/F and PCB. 
147 Determination of organochlorine pesticides (OCP) in baby food samples

148 Extraction of 2 to $10 \mathrm{~g}$ of $\mathrm{fw}$ infant formulae and $15 \mathrm{~g}$ of freeze dried solid foods and beverages was

149 performed in the same way as for the PCDD/F. Cleanup and instrumental analysis of OCP were 150 executed according to a former described procedure (Wang et al., 2009). Only 6 of 26 OCP studied 151 were below the detection limit and the concentration level was presented in $\mathrm{pg} / \mathrm{g}$ fw.

152

153

154 Samples of $20 \mathrm{~g}$ of fw infant formulae and $20 \mathrm{~g}$ of freeze dried solid foods and beverages were Soxhlet 155 extracted with $800 \mathrm{ml}$ toluene for $24 \mathrm{~h}$. The extract was concentrated to $4 \mathrm{ml}$ and then a clean-up step 156 was carried out on a sandwich column. This column consisted of $10 \mathrm{~g}$ active silica gel, $20 \mathrm{~g}$ silica gel $157\left(44 \% \mathrm{H}_{2} \mathrm{SO}_{4}\right), 40 \mathrm{~g}$ silica gel $\left(4 \% \mathrm{H}_{2} \mathrm{O}\right)$, and $10 \mathrm{~g} \mathrm{Na}_{2} \mathrm{SO}_{4}$ from bottom to top. The sample was eluted 158 with $900 \mathrm{ml} \mathrm{n}$-hexane. The eluate was concentrated and transferred to $200 \mu \mathrm{l}$ DMSO under $\mathrm{N}_{2}$ stream 159 at $45{ }^{\circ} \mathrm{C}$. Subsequently, the concentrate was eluted to a mixture DMSO/Isopropanol 4:1 as an optimal 160 carrier solvent for the bioassay.

161 EROD bioassay was performed using the rat liver cell line (HII4E) expressing cytochrome P4501A1 162 upon exposure to Aryl hydrocarbon receptor (AhR) agonists (Donato et al., 1993; Schwirzer et al., 163 1999). A H4IIE cell suspension was seeded into 96 well plates and incubated for 24 hours. Following 164 this, the cells were exposed in parallel to 2,3,7,8-tetrachlorodibenzo- $p$-dioxin (2,3,7,8-TCDD) standard 165 concentrations and samples keeping the ratio standard/medium and sample/medium at 0.005 . Blanks 166 were also carried out. The EROD induction caused by sample extracts after $72 \mathrm{~h}$ of incubation 167 (persistent compounds) was compared to the dose-response curve obtained with standards of 2,3,7,8168 tetrachlorodibenzo- $p$-dioxin (2,3,7,8-TCDD). The results were given as pg 2,3,7,8-TCDD toxicity 169 equivalent values (TE values) per gram sample.

170

171 E-Screen bioassay: TEXB assessment

172 MCF-7 cells were used in the test of estrogenicity according to a technique slightly modified 173 (Villalobos et al., 1995) from that originally described elsewhere (Soto et al., 1992). Briefly, $0.5 \mathrm{ml}$ of 174 each baby food extract including "starting" infant formulae (Mf, Sf and Hf) and pooled "follow-on" 175 infant formulae and solid foods and beverages (fMf+SFB5, fMf+SFB9, fSf+SFB5, fSf+SFB9, 176 fHAf+SFB5, and fHAf+SFB9) were evaporated to dryness under a gentle nitrogen stream. Then, the 177 extracts were resuspended in $10 \mathrm{ml}$ of experimental medium (10\% CD-FBS-supplemented phenol red178 free DMEM), vigorously shaken and left at rest for $30 \mathrm{~min}$, then filtered through a $0.22 \mu \mathrm{m}$ filter and 179 tested on MCF-7 cells at dilutions of 1:1 to 1:10,000. In each experiment, a dose-response curve $(0.1$ $180 \mathrm{pM}-1000 \mathrm{pM})$ of $17 \beta$-estradiol $\left(\mathrm{E}_{2}\right)$, and a negative control (cell treated only with hormone-free 181 medium) were included. The bioassay was terminated on day 6 (late exponential phase) by removing 182 the media from the wells, fixing the cells and staining them with sulphorhodamine-B (SRB). The 
183 proliferative effect (PE) was calculated as the ratio between the highest cell yield obtained with 100 $184 \mathrm{pM}$ of $\mathrm{E}_{2}$ and the proliferation of hormone-free control cells. The PEs obtained with 1:1 to 1:10,000 185 dilutions of individual extracts were converted to estradiol equivalents (Eeq) units by interpolation on 186 the estradiol dose-response curve and expressed as Eeq per gram of sample, as an estimation of the 187 total effective xenoestrogen burden (TEXB) (Rivas et al., 2001).

\section{Determination of BPA and its chlorinated derivatives in baby food samples}

190 An accurate and reproducible gas chromatographic-mass spectrometric (GC-MS) method was 191 developed to quantify BPA and its chlorinated derivatives in infant formulae. Sample of $0.4 \mathrm{~g}$ of $\mathrm{fw}$ 192 infant formula was extracted involving a protein precipitation step with acetonitrile and a solid-phase 193 extraction (SPE) step using Isolute $\mathrm{C}_{18}$ cartridges. After isolation, the solvent was evaporated with 194 nitrogen stream and a silylation step was carried out using N,O-bis(trimethylsilyl) trifluoroacetamide 195 (BSTFA) and trimethylchloro silane (TMCS) (99:1,v/v). The silylated compounds were identified and 196 quantified by GC-MS using a ZB-5 MS column and selected-ion monitoring (SIM) mode. Bisphenol F 197 was used as internal standard.

199 Extraction of $0.5 \mathrm{~g}$ of freeze dried solid foods and beverages was carried out on ASE using $n$-hexane, 200 followed by a liquid-liquid extraction with acetonitrile and consequent cleaning with $n$-hexane. The 201 extracted sample was taken to dryness with a gentle stream of nitrogen and reconstituted with 202 deionised water. A SPE step was carried out using isolute $\mathrm{C}_{18}$ cartridges in order to clean up the 203 sample. The solvent was removed and a silylation step was performed using BSTFA and TMCS. 204 Finally, the silylated compounds were identified and quantified by GC-MS.

The linearity of the calibration curves was tested according to the Analytical Methods Committee 207 (AMC, 1994). The results for the intercept (a), slope (b), correlation coefficient $\left(\mathrm{R}^{2}\right)$, and probability 208 level of the lack-of-fit test and for the linearity, precision, accuracy, sensitivity, and selectivity of the 209 overall assay have been presented elsewhere (Del Olmo et al., 2005; Zafra et al., 2003; Ballesteros et 210 al., 2006). The limit of detection (LOD) and the LOQ for BPA and its chlorinated derivatives in infant 211 formula samples ranged from 0.8 to 1.7 and 2.6 to $5.8 \mathrm{ng} / \mathrm{g}$, respectively and from 1.5 to 3.3 and 4.9 to $21210.9 \mathrm{ng} / \mathrm{g}$, respectively, for solid foods and beverages samples. The methodology was validated using 213 recovery studies with spiked samples. Recoveries ranged from 85.3 to $108.4 \%$, with mean values of 99.0\% (BPA), $101.2 \%$ (ClBPA), 92.9\%, $\left(\mathrm{Cl}_{2} \mathrm{BPA}\right), 93.3 \%\left(\mathrm{Cl}_{3} \mathrm{BPA}\right)$, and $93.5 \%\left(\mathrm{Cl}_{4} \mathrm{BPA}\right)$.

\section{Elaboration of the monthly diets for EU babies for the first 9 months of life}

217 The mean daily dietary exposure to PCDD/F, PCB, OCP, and BPA was calculated based on the 218 estimated average amount of infant formulae ( $\mathrm{ml} /$ day) and solid foods and beverages ( $\mathrm{g} /$ day) 
220 (fw)/kg bw for the "starting" formulae consumed by infants 0-1, 1-2, 2-3, and 3-4 months of age, 221 respectively; 12.8, 8.0, 4.6, 4.4 and $4.2 \mathrm{~g}(\mathrm{fw}) / \mathrm{kg}$ bw for the "follow-on" formulae consumed by 222 infants 4-5, 5-6, 6-7, 7-8 and 8-9 months of age, respectively; and 28.8, 54.7, 72.6, 70.2 and $71.9 \mathrm{~g}$ 223 (fw)/kg bw for the solid foods and beverages consumed by infants 4-5, 5-6, 6-7, 7-8 and 8-9 months of 224 age, respectively. Further details have been reported elsewhere (Piccinelli et al., 2010).

225 The results of compound determination were converted into daily dietary exposure based on the daily 226 consumption of the baby foods and bw of infant at a certain month, respectively. In order to establish a 227 meaningful comparison the calculated values were additionally expressed in the same unit as the 228 tolerable daily intakes established by international expert committees. 229

\section{Results and Discussion}

231 Levels of PCDD/F and dioxin-like PCB and TE-EROD value baby foods

232 Table 2 presents the LB and UB for the levels of PCB and PCDD/F in infant formulae and solid foods 233 and beverages based on chemical analysis.

234 (Table 2 here) 235

236 No or low levels of PCDD/F or PCB were detected in the solid foods and beverages and negligible 237 PCB levels were detected in the infant formulae. With regard to infant formulae a LB range of 0.01 to $2380.05 \mathrm{PCDD} / \mathrm{F}$ (WHO-TEQ) pg/g fw that correspond to 0.04 to 0.2 (WHO-TEQ) pg/g lipid (the 239 package labelled lipid content of approximately $25 \mathrm{~g}$ per $100 \mathrm{~g}$ fw) was estimated. For comparison, 240 slightly higher median value of total WHO-TEQ of $0.07 \mathrm{pg} / \mathrm{g}$ fw were suggested in infant formulae 241 from the Swedish market (Broman et al., 2009). However, elevated PCDD/F level of 0.11 PCDD/F 242 (WHO-TEQ) pg/g fw (0.44 PCDD/F (WHO-TEQ) pg/g lipid) was found for the "starting" 243 hypoallergenic infant formula (HAf). It was also noted similar PCDD/F UB level was detected for 244 both hypoallergenic infant formulae, i.e. HAf and fHAf. In fact, all these concentrations were lower 245 than reported $0.7 \pm 0.2 \mathrm{pg}$ and 0.98 (WHO-TEQ) pg/g lipid in formula milk from southern Taiwan (Hsu 246 et al., 2007) and Slovak Republic (Chovancová et al., 2005) markets, respectively and far lower than 247 the total median $\mathrm{TEQ}_{98}$ of $15 \mathrm{pg} / \mathrm{g}$ lipid in mother milk from randomly recruited primiparas $(\mathrm{N}=183)$ 248 who lived in Uppsala Country and delivered between 1996 and 2006 (Lignell et al., 2009). Recent 249 EFSA report on monitoring of dioxin level in food and feed including "Infant and baby food" group 250 suggested mean total dioxins equal to 0.42 pg TEQ $\mathrm{WHO}_{98} / \mathrm{g}$ lipid (EFSA, 2010).

251 The induction of EROD activity was used as a well-established biomarker for assessing the exposure 252 to stressors such as mixture of contaminants able to elicit a response at the AhR level. However, no TE 253 levels higher than the LOD (0.5 pg/g fw) and LOQ (3.5 pg/g fw) were observed. Therefore, the 254 present study can not use the EROD data for further calculations of dietary exposure to dioxin-like 255 compounds. However, the use of a bioanalytical tool is important since it allows to investigate 
256 possible interactions between different chemicals present in the sample. These possible effects are not 257 considered when single analytical determinations are performed.

\section{Level of organochlorine pesticides $(O C P)$ in baby foods}

260 Among of the different isomers of $\mathrm{HCH}$, only $\alpha-\mathrm{HCH}$ in Sf and fHAf and only $\beta$-HCH in fHAf were detected in infant formulae (Table 3). The $\alpha$-, $\beta$-, and $\gamma$-isomers of $\mathrm{HCH}$ were present in all solid foods and beverages samples, with a monthly stepwise increase in the content of the $\alpha-\mathrm{HCH}$ level as the diet became more and more varied. Since the nervous system is among the vulnerable targets for lindane exposure and perinatal exposure to lindane has been associated with the development of Parkinson's disease later in life (Heusinkveld et al., 2010) the $\gamma$ - $\mathrm{HCH}$ isomer (lindane) is the most important one within the HCHs. This compound was found predominantly in the solid foods and beverages samples, although still at levels much lower than the maximum residue limits (MRL) proposed for lindane i.e. $0.010 \mathrm{mg} / \mathrm{kg}$ lipid (FAO/WHO, 2006).

(Table 3 here)

As also shown in Table 3, in almost all of the baby food samples analysed, DDTs were present at 272 levels above the detection limit. In addition, in both types of baby food (infant formulae and solid 273 foods and beverages) the levels of 4,4'-DDT, 2,4'-DDT, 4,4'-DDD, 2,4'-DDD and 2,4'-DDE were 274 relatively similar. Out of the six DDTs analysed, 4,4'-DDE was present at highest levels (20.9 pg/g fw) 275 in the milk-based formulae and in solid foods and beverages where the corresponding levels of SFB8 276 and SFB9 were 45.5 and $37.0 \mathrm{pg} / \mathrm{g}$ fw, respectively. On a lipid basis, Mf value was $0.08 \mathrm{ng} / \mathrm{g}$, which is 277 far lower than the level of p,p'-DDE in breast milk reported Czech Republic $600 \mathrm{ng} / \mathrm{g}$ lipid (Cerna et 278 al., 2010).

Heptachlor, cis-chlordane, trans-heptachlorepoxide and endrin were not detected in any of the samples 281 analysed (Table 3). However, trans-chlordane, oxy-chlordane and aldrin were present at negligible 282 concentrations in solid foods and beverages (100, 60 and 40\%, respectively), in particular food 283 designed for 8- and 9-month-old infants. Although cis-heptachlorepoxid was found in all of the baby 284 foods, with the highest level of $0.023 \mathrm{ng} / \mathrm{kg} \mathrm{fw}(0.092 \mathrm{ng} / \mathrm{kg}$ lipid) in fMf, it levels were well below the MRL of $6 \mu \mathrm{g} / \mathrm{kg}$ lipid (FAO/WHO, 2006).

Among the OCP, endosulfan isomers were mostly dominant in investigated milk- and hypoallergenic288 based infant formulae. The determined concentrations were 139, 132 and $148 \mathrm{pg} / \mathrm{g}$ of fw for Mf, HAf 289 and fHAf, respectively which is below the MRL ( $0.1 \mathrm{mg} / \mathrm{kg}$ lipid) of endosulfan in milk (FAO/WHO, 290 2006). Although industrialized nations have restricted or banned many organochlorine pesticides (e.g., 291 endosulfans), according to the available information, Spain is the main consumer of endosulfans 292 within the European Union, accounting for almost half of the total consumption (Cerrillo et al., 2005). 
In fact, $20 \%$ of samples of milk-based infant formulas from Spain were positive for this contaminant, 294 which is identified as an endocrine disruptor (Mezcua et al., 2007). Also, reports on human exposure 295 to persistent OCP have indicated considerable exposure to endosulfans, as the fact that they have been 296 detected in placenta, umbilical cord blood and breast milk of women as well as in adipose tissue of children living in Southern Spain (Lopez-Espinosa et al., 2008).

The result of the study revealed that out of total 26 OCP investigated only 6 were found below the LOD. Although in all baby food samples investigated the detected OCP levels were much lower than the MRL, nevertheless, there is need of continuous monitor from infant food safety point of view and also time tendency after restriction and ban of some OCP. It indicates also the high degree of dispersion of these substances in the environment as well as the distribution of OCP in the soil-plant system.

\section{Estrogenicity of baby food extracts in the E-Screen bioassay}

307 In order to estimate the estrogenicity of the samples, a total of nine baby food extracts of "starting" 308 infant formula (Mf, Sf, HAf) and pooled "follow-on" infant formulae and solid foods and beverages 309 (fMf+SFB5, fMf+SFB9, fSf+SFB5, fSf+SFB9, fHAf+SFB5, and fHAf+SFB9) were tested using a 310 MCF-7 cell based proliferation assay (E-Screen bioassay). The biomarker of estrogenicity (TEXB) 311 was developed to measure the cumulative estrogenicity of chemicals using the E-Screen bioassay. 312 Table 4 lists the TEXB values (mean and standard deviation) expressed as Eeq/g sample. Because all 313 tested samples were toxic for MCF-7 cells at 1:1 dilution, due to solvent toxicity, we tested serial 314 dilutions up to $1: 10,000$ in order to obtain measurable estrogenicity of the fractions. TEXB levels 315 ranged from undetectable ( $<1 \mathrm{pM}$ Eeq) to $73.60 \mathrm{pM}$ Eeq/g, the maximal estrogenicity observed.

\section{6 (Table 4 here)}

318 Estrogenicity was $<1 \mathrm{pM}$ Eeq/g in $\mathrm{Mf}$ and HAf samples, whereas the highest TEXB values 319 corresponded to the soy-based formula samples. These findings are in agreement with recent findings 320 by Riu et al. (2008) on the estrogenicity of the same soy-based formula samples, using a reporter gene 321 assay based on MELN and HELN bioluminescent cells. They observed a preference for transactivation 322 of $\mathrm{ER} \beta$ versus $\mathrm{ER} \alpha$, a type of transactivation signal profile previously described for estrogenic 323 compounds such as phytoestrogens (Escande et al., 2006). Interestingly, they confirmed the presence 324 of several phytoestrogens identified as aglycones (daidzein, glycitein, and genistein) using ER $\alpha$-based 325 affinity columns. Therefore, the estrogenicity of soy-based formula samples can be assumed to derive 326 mostly from natural chemicals (e.g. phytoestrogens) rather than from man-made xenoestrogens.

327 Concerns have been raised by the scientific community about the potential risks to infant health of 328 soy-based formula consumption, due to its phytoestrogen content. Tuohy (2003), in a review of the 329 conflicting evidence on the risks and benefits of soy phytoestrogens, denounced the absence of 
330 adequate scientific research that quantifies the level of risk for infants. He suggested the need for a 331 precautionary approach to be taken in relation to the potential developmental effects of the 332 consumption of pharmacologically active compounds in infancy and childhood.

Levels of BPA and its chlorinated derivatives in baby foods

335 Eleven baby foods including infant formulae (Mf, Sf, HAf, fMf, fSf and fHAf,) and solid foods and 336 beverages (SFB5, SFB6, SFB7, SFB8, and SFB9) were analysed for BPA and its derivatives and the 337 results were presented in $\mathrm{ng} / \mathrm{g}$ of fw. No detectable levels were found in infant formulae samples, with 338 the exception of the BPA concentration (3.60 ng/g of sample) being detected in HAf. This result is in 339 agreement with previous studies that report BPA concentration in canned infant formula samples 340 (powdered and whole milk) ranging from <1.7 to $15.2 \mathrm{ng} / \mathrm{g}$ (Maragou et al., 2006). In addition, the 341 concentrations reported in the present work fall within the range of previously published 342 measurements of BPA in canned liquid infant formula from the United States (Ackerman et al., 2010) 343 as well as Canada (Cao et al., 2008) and are much lower than the BPA levels reported in powdered 344 infant formula purchased from the local Taiwan market that ranged from 45 to $113 \mathrm{ng} / \mathrm{g}$ (Kuo and 345 Ding, 2004).

347 Regarding solid foods and beverages samples investigated the BPA levels were bellow the determined 348 LOQ level of $1.5 \mathrm{ng} / \mathrm{g}$. However, a concentration of $17.35 \mathrm{ng} / \mathrm{g}$ of sample was detected in the food 349 designed for 9 month-old infants (SFB9). To date, several studies have been dedicated to determine 350 BPA levels in food and via food packaging (Muncke, 2009). In general, concentrations of BPA in 351 canned food products differ considerably among food types. For example, BPA values range from 7.8 352 to $24.4 \mathrm{ng} / \mathrm{g}$ in canned fruits and from 55 to $103 \mathrm{ng} / \mathrm{g}$ in canned vegetables from the Spanish market 353 (Garcia-Prieto et al., 2008). By contrast, the mean of BPA concentrations in canned vegetables from 354 Canadian (Cao et al., 2010) and Italian markets (Grumetto et al., 2008) were relatively low (less than $35510 \mathrm{ng} / \mathrm{g})$. 356

357 BPA chlorinated derivatives (ClBPA, $\mathrm{Cl}_{2} \mathrm{BPA}, \mathrm{Cl}_{3} \mathrm{BPA}$ and $\mathrm{Cl}_{4} \mathrm{BPA}$ ) were not detectable in SFB5, 358 SFB6, SFB7, while these compounds were below LOQ (4.9 ng/g) in SFB8 sample, and subsequently $359 \mathrm{Cl}_{3} \mathrm{BPA}$ and $\mathrm{Cl}_{4} \mathrm{BPA}$ were quantified at concentrations 12.45 and $5.11 \mathrm{ng} / \mathrm{g}$ of sample, respectively, in 360 SFB9. In general, a tendency to higher concentrations of BPA and its derivatives was found in 361 industrial solid foods and beverages with increasing months.

363 Daily intake of $P C D D / F$, dioxin-like PCB, OCP and BPA of non-breasted infants (0-9 month aged) 364 fed with baby foods

365 The dietary exposure to PCDD/F and PCB (pg WHO-TEQ/kg bw/day) of 0-9 month-old infants was 366 estimated considering the LB levels in "starting" Mf, Sf, HAf (for infants 0-4 months), "follow-on" 
367 fMf, fSf, fHAf infant formula, respectively, and solid foods and beverages (SFB5-SFB9) and their 368 foods consumption (Table 5). The study does not consider the additional drinking water exposure as 369 well as the specific exposure at month $6^{\text {th }}$ and $9^{\text {th }}$ that may arise during crawling and soil ingestion.

370 (Table 5 here)

371

$372 \mathrm{PCDD} / \mathrm{F}$ and PCB exposure appeared to decrease from month to month, due to the reduced 373 consumption of formula per $\mathrm{kg}$ bw. Moreover, exposure to dioxin-like PCB via the six typologies of 374 infant formulae during the first 9 months of life was far lower than the exposure to PCDD/F (Table 5).

375 Exposure of 5-9 month-old infants to PCB via solid foods and beverages investigated was estimated to 376 be between 0 and $0.73 \mathrm{pg}$ WHO-TEQ $/ \mathrm{kg}$ bw/day, which is higher than the corresponding value for 377 PCDD/F from fifth to ninth month of postnatal life. 378

379 The highest estimated exposure to PCDD/F of more than $2 \mathrm{pg}$ WHO-TEQ/kg bw/day was exhibited by 380 infants consuming HAf who had an average body weight of less than $6.4 \mathrm{~kg}$ (unique $\mathrm{LB}$ and UB $381 \mathrm{PCDD} / \mathrm{F}$ concentration levels). In general, HAf is occasionally recommended by pediatricians for 382 babies who have a severe problem digesting cow's milk based formula or soy formula. HAf require 383 more intensive processing than Mf and Sf and more processing tend to introduce more contamination. 384 Hypoallergenic formulae are processed by enzymatic hydrolysis of different protein sources such as 385 bovine casein/whey and soy followed by further processing such as heat treatment and/or 386 ultrafiltration, or they are based on amino acid mixtures (Høst and Halken, 2004). Exposure to dioxins 387 of infants up to two months of age through HAf is of potential concern. Furthermore, consideration of 388 UB PCDD/F and PCB values in Mf and Sf may suggest critical dietary exposure for same bw group 389 infants such as $2.42 \pm 0.32$ and $1.99 \pm 0.26 \mathrm{pg}$ WHO-TEQ/kg bw/day, respectively. Although the similar 390 UB levels for PCDD/F in HAf and fHAf, lower than $2 \mathrm{pg}$ WHO-TEQ/kg bw/day exposure was 391 estimated during the weaning period due to differences in the pattern of consumption. 392

393 In general, excluding hypoallergenic formula the baby food items examined may expose 0-4- and 4-9394 month-old non-breast-fed infants to approximately 1 and $0.7 \mathrm{pg}$ WHO-TEQ/kg bw/day, respectively. 395 Similarly, the estimated chronic exposure to PCDD/F and dioxin-like PCB was $1.1 \mathrm{pg}$ WHO-TEQ/kg 396 bw/day for infants 5 months of age who consume infant formulae and vegetables available on the 397 Dutch market (Weijs et al., 2006). Overall, the dietary exposures estimated here do not exceed the 398 maximum TDI of $4 \mathrm{pg}$ WHO-TEQ/kg bw/day and moreover, are orders of magnitude lower than 399 reported total TEQ daily intake for breast-fed infants from Czech Republic 117- and 271 pg/kg bw/day 400 (Bencko et al., 2004), Turkey 37- and 70 pg/kg bw/day (Cok et al., 2009) and Spain 49.6 pg/kg 401 bw/day (Bordajandi et al., 2008). 402 
403 BPA level was detected only in the HAf out of the six infant formulae samples analysed. 404 Consequently, the estimated dietary exposure to BPA of $0.09,0.08,0.08$ and $0.07 \mu \mathrm{g} / \mathrm{kg}$ bw/day for 0 405 1, 1-2, 2-3 and 3-4 month aged infants are referred only to infants fed with this particularly infant 406 formulae. These dietary exposures are lower than the established TDI (50 $\mu \mathrm{g} / \mathrm{kg}$ bw/day) for BPA. 407 Regarding dietary exposure during the weaning period, a value of $1.7 \mu \mathrm{g} / \mathrm{kg}$ bw/day for $8-9$ months of 408 age infants was estimated. For solid foods and beverages consumed in the fifth and eighth months of 409 life, the BPA and chlorinated derivatives levels were lower than the determined LOQ range.

411 In general, only low levels of OCP were detected in the samples of baby food investigated. The 412 highest DDT daily exposure $0.0001 \mu \mathrm{g} / \mathrm{kg}$ bw was estimated for 4-5- month-old infants fed fMf, a 413 value below the limit of $10 \mu \mathrm{g} / \mathrm{kg}$ bw/day (FAO/WHO, 2000). Indeed, the daily dietary exposure to 414 DDT varies considerably among regions. The lowest dietary exposure has been observed in countries 415 where restriction and ban of DDT had been executed earliest (Sweden, Germany and Norway). Due to 416 later termination of production and restricted use of DDT, higher dietary exposure was reported in 417 Poland, the Czech Republic and Russia. In this regard, our results seems to be comparable with the 418 Canadian data (Hoover, 1999) for infants consuming breast milk, but lower than the dietary exposures 419 of $8 \mu \mathrm{g} / \mathrm{kg}$ bw recently estimated in Poland (Szyrwińska and Lulek, 2007) or Czech Republic (Cerna 420 et al., 2010) daily.

422 With regard to $\alpha$-, $\beta$ - and $\gamma$ - $\mathrm{HCH}$, the worst-case scenario would involve exposure to $0.6,0.02$ and 0.6 $423 \mathrm{ng} / \mathrm{kg}$ bw/day for infants consuming solid foods and beverages during the eighth month (BFB8), fHAf 424 during the fourth month and solid foods and beverages during the fifth month of life (BFB5), 425 respectively. However, all of these values are also very low compared to the Tolerable Daily Intakes 426 (TDI) of 5, 1 and $12.5 \mu \mathrm{g} / \mathrm{kg}$ bw/day, respectively (DFG, 1982).

\section{Conclusions}

429 The present assessment of levels of four classes of endocrine disrupting compounds: PCDD/F, PCB, 430 OCP and BPA and its derivatives in formulae and solid foods and beverages designed for infants 431 focused on the products with the largest shares of the market in $22 \mathrm{EU}$ countries. In addition, the 432 dietary exposure to these contaminants in the first 9 months of life of non-breast-fed infants was 433 estimated. The results were compared with established tolerable daily intakes. The established special 434 regulations for infants and children nutrition were also considered whereas here presented scientific 435 results could be used to improve our current knowledge on potential exposure to nuclear receptor 436 modulators through calculation in the different scenarios. Although direct analyses in human 437 biological samples (e.g. urine, blood) are known to be the best estimators of total exposure to some of 438 these contaminants, the aim of the present study was to identify and quantify potential sources of 439 exposure in infant diet. In sum the following findings were found: 
440

441

442

443

444

445

446

447

448

449

450

451

452

453

454

455

456

457

458

459

460

461

462

463

464

465

466

467

468

469

470

471

472

473

474

a. Using chemical target analysis the levels of PCDD/F and PCB in baby foods were low, with highest value of $0.11 \mathrm{pg} / \mathrm{g}$ ( $0.44 \mathrm{pg} / \mathrm{g}$ lipid) being detected in HAf. The sensitivity of the EROD bioassay was not high enough to calculate possible AhR inducer intakes at these low levels.

b. Due to infant high food consumption per kg bw of the infants, the determined low PCDD/F and PCB concentrations in baby foods may contribute to a dietary exposure of 0.14 to $1.27 \mathrm{pg}$ WHO-TEQ/kg bw/day for 0-9 months non-breastfed infants. The study notified that $0-4$ months aged infants consuming HAf may have dietary exposure of more than 2 pg WHOTEQ/kg bw.

c. Only 6 of 26 OCP studied were found below the LOD, implying a wide exposure of this susceptible population, even within the MRL.

d. TEXB assessment resulted in an estrogenicity in the range from undetectable $(<1 \mathrm{pM} \mathrm{Eeq/g})$ to $73.60 \mathrm{pM} \mathrm{Eeq/g} \mathrm{(maximal} \mathrm{estrogenic} \mathrm{activity),} \mathrm{the} \mathrm{latter} \mathrm{for} \mathrm{soy-based} \mathrm{formula} \mathrm{samples,}$ therefore attributable to phytoestrogens content.

e. Among investigated baby foods BPA was only found in HAf $(3.60 \mathrm{ng} / \mathrm{g})$ and in solid foods and beverages designed for 9 month-old infants $(17.35 \mathrm{ng} / \mathrm{g})$. In addition, the $\mathrm{Cl}_{3} \mathrm{BPA}$ and $\mathrm{Cl}_{4} \mathrm{BPA}$ concentrations were only detected in solid foods and beverages designed for 9 monthold infants at levels of 12.45 and $5.11 \mathrm{ng} / \mathrm{g}$ of sample, respectively.

Finally, the levels of contaminants detected in major commercial baby food products sold in the EU and the estimated dietary exposure by non-breast-fed infants are lower in magnitudes than those reported for nursing infants. However, and more importantly, low exposure to environmental chemicals, especially in the first months of life, must also take account of possible additive effects of mixture of chemicals. Indeed combinations may cause an effect even at concentrations of each individual chemical that alone would not produce measurable consequences. Further research is warranted to investigate and interpret the levels of endocrine disruptors. These results should provide a basis for recommendations concerning the risks posed by commercial baby foods to the health of young children.

\section{Acknowledgements}

The authors would like to thank all CASCADE partners who assisted in acquisition of information and shopping of baby food products, namely Ingemar Pongratz, Lars-Arne Haldosen and Jean-Pierre Cravedi. The study was financial supported by the European Union network CASCADE (FOOD-CT2003-506319) within the frame of WP19 projects (bread project and babyfood project). 


\section{References}

Ackerman LK, Noonan GO, Heiserman WM, Roach JA, Limm W, Begley TH. 2010. Determination of bisphenol A in U.S. infant formulas: updated methods and concentrations. J. Agric. Food Chem. 58: 2307-2313.

Ahlborg UG, Lipworth L, Titus-Ernstoff L, Hsieh CC, Hanberg A, Baron J, Trichopoulos D, Adami HO. 1995. Organochlorine compounds in relation to breast cancer, endometrial cancer, and 481 482 463-531.

Analytical Methods Committee (AMC).1994. Is my calibration linear? Analyst. 119: 2363-2366.

Ballesteros O, Zafra A, Navalón A, Vílchez JL. 2006. Sensitive gas chromatographic-mass spectrometric method for the determination of phthalate esters, alkylphenols, bisphenolA and their chlorinated derivatives in wastewater samples. J. Chromatogr. A. 1121: 154-162.

Bencko V, Cerna M, Jech L, Smid J. 2004. Exposure of breast-fed children in the Czech Republic to PCDDs, PCDFs, and dioxin-like PCBs. Environ. Toxicol. Phar. 18: 83-90.

Bordajandi L.R., Abad E., Gonzalez M.J. 2008. Occurrence of PCBs, PCDD/Fs, PBDEs and DDTs in Spanish breast milk: enantiomeric fraction of chiral PCBs, Chemosphere 70: 567-575.

Broman F, Aune M, Eskhult G. 2009. Results from the Swedish monitoring of PCDD/F and dioxin-like PCBs in foodstuff 2006-2008. Organohal. Comp. 71, 1689-1693.

Cao XL, Corriveau J, Popovic S. 2010. Bisphenol a in canned food products from canadian markets. J. Food Prot. 73: 1085-1089.

Cao XL, Dufresne G, Belisle S, Clement G, Falicki M, Beraldin F, Rulibikiye A. 2008. Levels of bisphenol A in canned liquid infant formula products in Canada and dietary intake estimates. J. Agric. Food Chem. 56: 7919-7924.

Cattaneo A. 2008. Breastfeeding - Occurrence. In: EUPHIX, EUphact. Bilthoven: RIVM. Available from: $<$ http://www.euphix.orgEUphact/Determinantsofhealth/Healthbehaviours/Breastfeeding $>$, $<$ بttp://www.euphix.org/object_document/o5130n27421.html>

CDC. Breastfeeding among U.S. children born 1999-2006, CDC National Immunization Survey. Available from: http://www.cdc.gov/breastfeeding/data/nis_data/index.htm. Accessed March 23, 2010.

Cerna M, Bencko V, Brabec M, Smid J, Krskova A, Jech L. 2010. Exposure assessment of breast-fed infants in the Czech Republic to indicator PCBs and selected chlorinated pesticides: Arearelated differences. Chemosphere. 78: 160-168.

Cerrillo I, Granada A, López-Espinosa MJ, Olmos B, Jiménez M, Caño A, Olea N, OleaSerrano MF. 2005. Endosulfan and its metabolites in fertile women, placenta, cord blood, and human milk. Environ. Res. 98: 233-239.

Chovancová J, Kočan A, Jursa S. 2005. PCDDs, PCDFs and dioxin-like PCBs in food of animal origin (Slovakia). Chemosphere. 61: 1305-1311. 
Cok I, Donmez MK, Uner M, Demirkaya E, Henkelmann B, Shen H, Kotalik J, Schramm K-W. 2009. Polychlorinated dibenzo-p-dioxins, dibenzofurans and polychlorinated biphenyls levels in human breast milk from different regions of Turkey. Chemosphere. 76: 1563-1571.

Del Olmo M, Zafra A, Suarez B, Gonzalez-Casado A, Taoufiki J, Vilchez JL. 2005. Use of solid-phase microextraction followed by on-column silylation for determining chlorinated bisphenol A in human plasma by gas chromatography-mass spectrometry. J. Chromatogr. B. 817: 167-172.

Deutschen Forschungsgemeinschaft (DFG). 1982: Hexachlorcyclohexan-Kontamination -

519 Ursachen, Situation und Bewertung. Kommission zur Prüfung von Rückständen in Lebensmitteln,

520 Mitteilung IX, H. Boldt Verlag, Boppard.

Donato MT, Gomez-Lechon MJ, Castell JV. 1993. A micro assay for measuring cytochrome P450IA1 and P450IIB1 activities in intact human and rat hepatocytes cultured on 96-well plates. Anal. 523 Biochem. 213: 29-33.

Dourson M, Charnley G, Scheuplein R, Barkhurst M. 2004. Differential sensitivity of children and adults to chemical toxicity. Hum. Ecol. Risk Assess. 10: 21-27.

Escande A, Pillon A, Servant N, Cravedi JP, Larrea F, Muhn P, Nicolas JC, Cavaillès V, Balaguer P. 2006. Evaluation of ligand selectivity using reporter cell lines stably expressing estrogen receptor alpha or beta. Biochem. Pharmacol. 71: 1459-1469.

European Commission (EC), 2004. EU Project on Promotion of Breastfeeding in Europe.

530 Protection, promotion and support of breastfeeding in Europe: a blueprint for action, Directorate

531 Public Health and Risk Assessment, Luxembourg, 2004. Available from:

532 http://europa.eu.int/comm/health/ph_projects/2002/promotion/promotion_2002_18 en.htm

European Food Safety Authority (EFSA), 2006. Opinion of the Scientific Panel on Food 534 Additives, Flavourings, Processing Aids and Materials in Contact with Food on a request from the 535 Commission related to 2,2-BIS(4-HYDROXYPHENYL)PROPANE (Bisphenol A) (Question No 536 EFSA-Q-2005-100) Adopted on 29 November 2009. 428: 1-75 Available from: 537 http://www.efsa.europa.eu/en/scdocs/doc/428.pdf

538 European Food Safety Authority (EFSA), 2010. EFSA Panel on food contact materials, 539 enzymes, flavourings and processing aids (CEF). Scientific Opinion on Bisphenol A: evaluation of a 540 study investigating its neurodevelopmental toxicity, review of recent scientific

541 literature on its toxicity and advice on the Danish risk assessment of Bisphenol A. EFSA Journal 542 2010;8(9):1829. [110 pp.] doi:10.2903/j.efsa.2010.1829. Available from: 543 http://www.efsa.europa.eu/en/scdocs/doc/1829.pdf

544 European Food Safety Authority (EFSA), 2010. Results of monitoring of dioxin levels in food 545 and feed. EFSA Journal. 8, 1385 Available from: http://www.efsa.europa.eu/en/scdocs/doc/1385.pdf 546 Fernandez MF, Arrebola JP, Taoufiki J, Navalón A, Ballesteros O, Pulgar R, Vilchez JL, Olea 547 N. 2007. Bisphenol-A and chlorinated derivatives in adipose tissue of women. Reprod. Toxicol. 24: 
Food and Agricultural Organization/ World Health Organisation (FAO/WHO). 2000. Report of the Joint Meeting of the FAO Panel of Experts on Pesticide Residues in Food and the Environment and the WHO Core Assessment Group. Geneva.2000 Available from:

http://books.google.it/books?id=h3ScCfUD47sC\&printsec=frontcover\&dq=2000+Pesticide+Res 553 idues+in+Food:+DDT+jecfa\&source=bl\&ots=esAYYeaugD\&sig=v63TX5ZQjTns167FyzTYhMxLKr

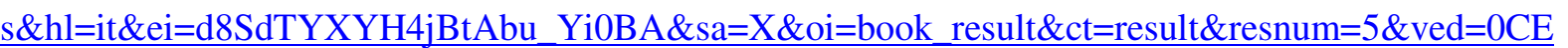
MQ6AEwBA\#v=onepage \&q=2000\%20Pesticide\%20Residues\%20in\%20Food\%3A\%20DDT\%20jecf $\mathrm{a} \& \mathrm{f}=$ false

558

559

Food and Agricultural Organization/ World Health Organisation (FAO/WHO). 2006. Codex maximum limits for pesticides residues. Rome: Codex Alimentarius Commission, FAO and WHO

Fukazawa H, Watanabe M, Shiraishi F, Shiraishi H, Shiozawa T, Matsushita H, Terao Y. 2002. Formation of chlorinated derivatives of bisphenol $\mathrm{A}$ in waste paper recycling plants and their estrogenic activities. J. Health Sci. 48: 242-249.

Garcia-Prieto A, Lunar L, Rubio S, Bendito DP. 2008. Decanoic acid reverse micelle-based coacervates for microextraction of bisphenol A from canned vegetables and fruits. Anal. Chem. Acta. 617: 51-58.

Grumetto L, Montesano D, Seccia S, Albrizio S, Barbato F. 2008. Determination of bisphenol a and bisphenol B residues in canned peeled tomatoes by reversed-phase liquid chromatography. J. Agric. Food Chem. 56: 10633-10637.

Heusinkveld HJ, Thomas GO, Lamot I, van den Berg M, Kroese ABA, Westerink R. 2010. Dual actions of lindane ( $\gamma$-hexachlorocyclohexane) on calcium homeostasis and exocytosis in rat PC12 cells. Toxicol. Appl. Pharmacol. 248: 12-19.

Hoover S.M. 1999.Exposure to persistent organochlorines in Canadian breast milk: a probabilistic assessment. Risk Anal. 19: 527-545.

Høst, A., Halken, S. 2004. Hypoallergenic formulas - when, to whom and how long: after more than 15 years we know the right indication!. Allergy. 59: 45-52.

Hsu JF, Guo YL, Liu CH, Hu SC, Wang JN, Liao PC. 2007. A comparison of PCDD/PCDFs exposures in infants via formula milk or breast milk feeding. Chemosphere. 66: 311-319.

Joint FAO/WHO Expert Committee on Food Additives (JECFA). 2002. Safety Evaluation of certain food additives and contaminants: Polychlorinated dibenzodioxins, polychlorinated dibenzofurans and coplanar polychlorinated biphenyls. Available from: http://www.inchem.org/documents/jecfa/jecmono/v48je20.htm

Kang JH, Kondo F, Katayama Y. 2006. Human exposure to bisphenol A. Toxicology. 226: 7989.

Kersting M, Alexy U, Sichert-Hellert W, Manz F, Schoch G. 1998. Measured consumption of commercial infant food products in German infants: results from the DONALD study. Dortmund Nutritional and Anthropometrical Longitudinally Designed. J. Pediatr. Gastr. Nutr. 27: 547-552. 
Kitamura S, Suzuki T, Sanoh S, Kohta R, Jinno N, Sugihara K, Yoshihara S, Fujimoto N, Watanabe H, Ohta S. 2005. Comparative study of the endocrine-disrupting activity of bisphenol A and 19 related compounds. Toxicol. Sci. 84: 249-259.

Krauthacker B, Reiner E, Romanic SH. 2006. Monitoring of organochlorine pesticides (OCP), polychlorinated biphenyls (PCB), polychlorinated dibenzodioxins (PCDDs)and dibenzofurans (PCDFs), in human milk in Croatia since 1977. Toxicology Lett. 164: 175-176.

Kubwabo C, Kosarac I, Stewart B, Gauthier BR, Lalonde K, Lalonde PJ. 2009. Migration of bisphenol A from plastic baby bottles, baby bottle liners and reusable polycarbonate drinking bottles. Food Addit. Contam. 26: 928-937.

Kuo HW, Ding WH. 2004. Trace determination of bisphenol A and phytoestrogens in infant 596 formula powders by gas chromatography-mass spectrometry. J. Chromatogr. A. 1027: 67-74.

Lignell S, Aune M, Darnerud PO, Cnattingiusa S, Glynn A. 2009. Persistent organochlorine and organobromine compounds in mother's milk from Sweden 1996-2006: Compound-specific temporal trends. Environ. Res. 109: 760-767.

Liu H, Zhao H, Quan X, Zhang Y, Chen S. 2009. Formation of chlorinated intermediate from Bisphenol A in surface saline water under simulated solar light irradiation. Environ. Sci. Technol. 43: $7712-7717$.

Lopez-Espinosa MJ, Lopez-Navarrete E, Rivas A, Fernandez MF, Nogueras M, Campoy C, Olea-Serrano F, Lardelli P, Olea N. 2008. Organochlorine pesticide exposure in children living in southern Spain. Environ Res. 106: 1-6.

Lopez-Espinosa MJ, Granada A, Araque P, Molina-Molina JM, Puertollano MC, Rivas A, Fernández M, Cerrillo I, Olea-Serrano MF, López C, Olea N. 2007. Oestrogenicity of paper and cardboard extracts used as food containers. Food Addit. Contam. 24: 95-102.

Lorán S, Bayarri S, Conchello P, Herrera A. 2007. Evaluation of GC-ion trap-MS/MS methodology for monitoring PCDD/Fs in infant formulas. Chemosphere. 67: 513-520.

Maragou NC, Lampi EN, Thomaidis NS, Koupparis MA. 2006. Determination of bisphenol A in milk by solid phase extraction and liquid chromatography-mass spectrometry. J. Chromatogr. A. 1129: $165-173$.

Maragou NC, Makri A, Lampi EN, Thomaidis NS, Koupparis MA. 2008. Migration of bisphenol A from polycarbonate baby bottles under real use conditions. Food Addit. Contam. 25: 373383.

Mezcua M, Repetti MR, Agüera A, Ferrer C, García-Reyes JF, Fernández-Alba AR. 2007. Determination of pesticides in milk-based infant formulas by pressurized liquid extraction followed by gas chromatography tandem mass spectrometry. Anal. Bioanal. Chem. 389: 1833-1840.

Mueller J, Harden F, Toms LM, Symons R, Fürst. 2008. Persistent organochlorine pesticides in human milk samples from Australia. Chemosphere. 70: 712-720. 
Muncke J. 2009. Exposure to endocrine disrupting compounds via the food chain: Is packaging a relevant source? Sci. Total Environ. 407: 4549-4559.

Piccinelli R, Pandelova M, Le Donne, Ferrari M, Schramm K-W,Leclercq C. 2010. Design and preparation of market baskets of EU commercial baby foods for the assessment of infant exposure to 626 food chemicals and to their effects. Food Addit. Contam. Part A. 27: 1337-1351.

.Ramos L, Torre M, Laborda F, Marina ML. 1998. Determination of polychlorinated biphenyls in soybean infant formulas by gas chromatography. J. Chromatogr. A. 823: 365-372.

Riu A, Balaguer P, Perdu E, Pandelova M, Piccinelli R, Gustafsson JA, Leclercq C, Schramm 631 K-W, Dagnino S, Debrauwer L, Cravedi JP, Zalko D. 2008. Characterisation of bioactive compounds in infant formulas using immobilised recombinant estrogen receptor-alpha affinity columns. Food 632 Chem. Toxicol. 46: 3268-3278.

Rivas A, Fernandez MF, Cerrillo I, Ibarluzea J, Olea-Serrano MF, Pedraza V, Olea N. 2001. 634 Human exposure to endocrine disrupters: standardisation of a marker of estrogenic exposure in 635 adipose tissue. Acta Path. Micro. Im. A. 109: 185-197.

Schecter A, Fürst P, Fürst C, Meemken HA, Groebel W, Vu DC. 1989. Levels of 637 polychlorinated dibenzodioxins and dibenzofurans in cow's milk and in soy bean derived infant formulas sold in the United States and other countries. Chemosphere. 19: 913-918.

Schwirzer SMG, Hofmaier AM, Kettrup A, Nerdinger PE, Schramm K-W, Thoma H, Wegenke 641 2,3,7,8-Tetrachlorodibenzo-p-dioxin toxicity equivalents of environmental samples. Ecotox. Environ. 642 Safe. 41: 77-82.

Scientific Committee on Food (SCF). 2001. Opinion of the SCF on the risk assessment of 644 dioxins and dioxin-like PCBs in food. Update based on new scientific information available since the 645 adoption of the SCF opinion of 22nd November 2000. European Commission, Brussels.

Soto AM, Lin TM, Justicia H, Silvia RM, Sonnenschein C.1992. An in culture bioassay to 647 648 assess the estrogenicity of xenobiotics. In: Chemically Induced Alterations in Sexual Development: The Wildlife/Human Connection (Colborn T, Clement CR, eds). Princeton, NJ: Princeton Scientific 649 Publishing, 295-309.

650 Szyrwińska K, Lulek J. 2007. Exposure to specific polychlorinated biphenyls and some 651 chlorinated pesticides via breast milk in Poland. Chemosphere. 66: 1895-1903.

Takemura H, Ma J, Sayama K, Terao Y, Zhu BT, Shimoi K. 2005. In vitro and in vivo 653 estrogenic activity of chlorinated derivatives of bisphenol A. Toxicology. 14: 215-221.

Tuohy PG. 2003. Soy infant formula and phytoestrogens. J. Paediatr. Child. Health. 39: 401655 405.

Villalobos M, Olea N, Brotons JA, Olea-Serrano MF, Ruiz de Almodóvar JM, Pedraza V. 1995. 657 The E-screen assay: a comparison of different MCF7 cell stocks. Environ. Health Perspect. 103: 844658 850. 
659 Wang J, Bi Y, Pfister G, Henkelmann B, Zhu K., Schramm K-W. 2009. Determination of PAH, 660 PCB, and OCP in water from the Three Gorges Reservoir accumulated by semipermeable membrane 661 devices (SPMD). Chemosphere. 75: 1119-1127.

662 Weijs PJM, Bakker MI, Korver KR, Goor Ghanaviztchi K, Wijnen JH. 2006. Dioxin and dioxin663 like PCB exposure of non-breastfed Dutch infants. Chemosphere. 64: 1521-1525.

664 World Health Organisation (WHO). 2000. Assessment of the health risk of dioxins: re665 evaluation of the Tolerable Daily Intake (TDI): executive summary. Food Addit. Contam. 17: 223666240.

667 World Health Organisation (WHO). 2003. Instructions for electronic submission of data on 668 chemical contaminants in food and the diet. Global Environment Monitoring System - Food 669 Contamination Monitoring and Assessment Programme (GEMS/Food). Available from: 670 http://www.who.int/foodsafety/publications/chem/en/gemsmanual.pdf

671 Zafra A, Del Olmo M, Suarez B, Hontoria E, Navalón A, Vílchez JL. 2003. Gas 672 chromatographic-mass spectrometric method for the determination of bisphenol A and its chlorinated 673 derivatives in urban wastewater. Water. Res. 37: 735-742. 674 
Table 1. Infant age for inclusion of "infant formulae" and "baby foods and beverages"

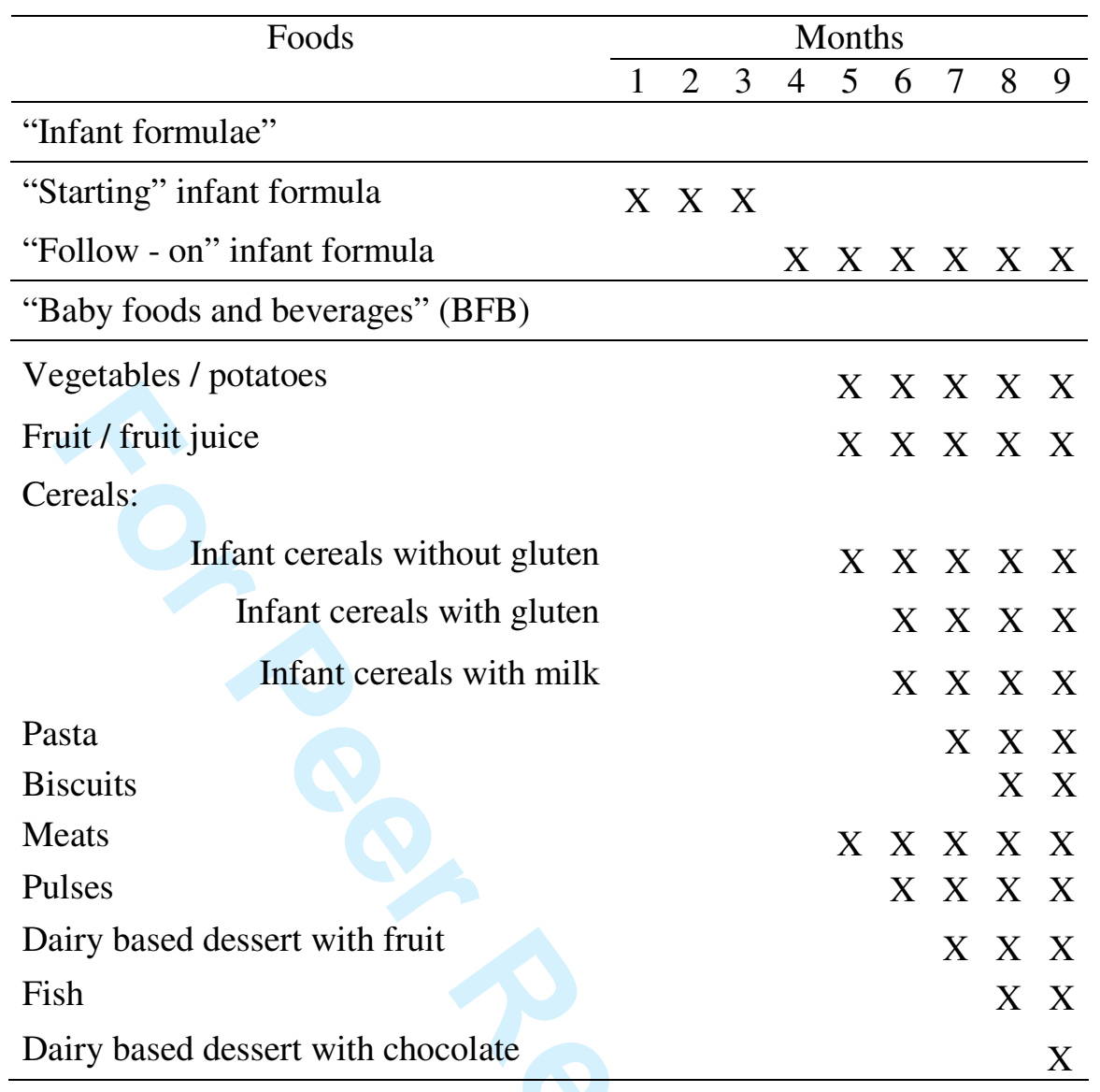


Table 2. Lower bound (LB) and upper bound (UB) concentration levels of PCDD/F and PCB (WHO-TEQ) pg/g fw in "infant formulae" and "baby foods and beverages" samples

\begin{tabular}{|c|c|c|c|c|c|c|c|c|c|c|c|c|}
\hline \multicolumn{2}{|c|}{ Type baby food } & Mf & $\mathrm{Sf}$ & HAf & fMf & $\mathrm{fSf}$ & fHAf & \multicolumn{5}{|c|}{ Baby foods and beverages } \\
\hline \multicolumn{2}{|c|}{$\begin{array}{c}\text { Infant age } \\
\text { (month) }\end{array}$} & \multicolumn{3}{|c|}{$0-4^{\text {th }}$ month } & \multicolumn{3}{|c|}{ up to the $5^{\text {th }}$ month } & $5^{\text {th }}$ & $6^{\text {th }}$ & $7^{\text {th }}$ & $8^{\text {th }}$ & $9^{\text {th }}$ \\
\hline $\begin{array}{c}\text { PCDD/F } \\
\text { (WHO-TEQ) }\end{array}$ & Lower bound (LB) & 0.04 & 0.05 & 0.11 & 0.04 & 0.02 & 0.01 & n.d. & 0.0035 & 0.00001 & 0.00002 & 0.0005 \\
\hline $\mathrm{pg} / \mathrm{g} \mathrm{fw}$ & Upper bound (UB) & 0.09 & 0.09 & 0.11 & 0.09 & 0.07 & 0.12 & 0.03 & 0.0436 & 0.0384 & 0.0640 & 0.0693 \\
\hline $\begin{array}{c}\text { PCB } \\
(\text { WHO-TEQ) }\end{array}$ & Lower bound (LB) & 0.0010 & 0.0003 & 0.0005 & 0.0030 & 0.0001 & 0.0006 & 0.0000 & 0.01 & 0.01 & 0.01 & 0.01 \\
\hline $\mathrm{pg} / \mathrm{g}$ fw & Upper bound (UB) & 0.0021 & 0.0013 & 0.0006 & 0.0031 & 0.0013 & 0.0017 & 0.17 & 0.01 & 0.01 & 0.01 & 0.01 \\
\hline
\end{tabular}

fw: fresh weight; n.d.: not detectable; Mf: "starting" infant formulae of milk-based; Sf: "starting" infant formulae of soy-based; HAf: "starting" infant formulae of hypoallergenic-based; fMf: "follow on" infant formulae of milk-based; fSf: "follow on" infant formulae soy-based; fHAf: "follow on" infant formulae hypoallergenic-based 
Table 3. OCP concentration level (pg/g fw) in "infant formulae" and "baby foods and beverages" samples

\begin{tabular}{|c|c|c|c|c|c|c|c|c|c|c|c|c|c|}
\hline Substance & Mf & Sf & HAf & fMf & $\mathrm{fSf}$ & fHAf & BFB5 & BFB6 & BFB7 & BFB8 & BFB9 & $\begin{array}{c}\text { LOD } \\
(\text { mean } \pm \text { STD })\end{array}$ & $\begin{array}{c}\text { LOQ } \\
\text { (mean } \pm \text { STD })\end{array}$ \\
\hline$\alpha-\mathrm{HCH}$ & n.d. & 2.7 & n.d. & n.d. & n.d. & 2.3 & 4.3 & 6.6 & 6.9 & 8.0 & 7.6 & $1.0 \pm 0.9$ & $2.0 \pm 1.8$ \\
\hline$\beta$-HCH & n.d. & n.d. & n.d. & n.d. & n.d. & 1.7 & 1.1 & 0.9 & 1.5 & 1.4 & 1.2 & $2.0 \pm 2.6$ & $4.0 \pm 5.2$ \\
\hline$\gamma-\mathrm{HCH}$ & n.d. & n.d. & n.d. & n.d. & n.d. & n.d. & 22.7 & 10.7 & 13.3 & 17.4 & 13.4 & $1.6 \pm 1.8$ & $2.9 \pm 3.6$ \\
\hline$\delta$ - $\mathrm{HCH}$ & n.d. & n.d. & n.d. & n.d. & n.d. & n.d. & n.d. & n.d. & n.d. & n.d. & n.d. & $2.1 \pm 2.7$ & $4.1 \pm 5.4$ \\
\hline$\varepsilon-\mathrm{HCH}$ & n.d. & n.d. & n.d. & n.d. & n.d. & n.d. & n.d. & n.d. & n.d. & n.d. & n.d. & $1.3 \pm 0.8$ & $2.3 \pm 1.7$ \\
\hline Pentachlorobenzene & n.d. & 4.2 & 7.3 & n.d. & n.d. & 6.4 & 0.28 & 3.7 & 8.2 & 27.4 & 122 & $0.2 \pm 0.2$ & $0.4 \pm 0.4$ \\
\hline Hexachlorobenzene & n.d. & 69.9 & 60.8 & n.d. & n.d. & 45.9 & n.d. & n.d. & n.d. & 0.52 & 8.9 & $1.8 \pm 1.8$ & $3.5 \pm 3.5$ \\
\hline 4,4'-DDT & n.d. & 5.8 & 1.3 & 7.6 & 8.6 & 1.8 & 2.1 & 1.9 & 2.2 & 5.6 & 3 & $0.6 \pm 0.6$ & $1.2 \pm 1.2$ \\
\hline 2,4'-DDT & 2.9 & 1.6 & n.d. & 2.7 & 1 & 0.84 & 0.9 & 0.8 & 0.9 & 1.9 & 1.1 & $0.6 \pm 0.6$ & $1.2 \pm 1.2$ \\
\hline 4,4'-DDD & 4.2 & 3.2 & 5.2 & 10.8 & 5.3 & 3.1 & 0.7 & 0.7 & 1.0 & 4.6 & 3.9 & $0.3 \pm 0.3$ & $0.5 \pm 0.5$ \\
\hline 2,4'-DDD & 2.4 & 0.84 & 1.5 & 2.4 & 1.7 & 0.84 & 0.1 & 0.1 & 0.1 & 1.3 & 0.9 & $0.2 \pm 0.2$ & $0.5 \pm 0.5$ \\
\hline 4,4'-DDE & 20.9 & 1.9 & 10.1 & 16.5 & 4.9 & 11.2 & 8.6 & 10.1 & 9.4 & 45.5 & 37.0 & $0.7 \pm 0.8$ & $1.4 \pm 1.5$ \\
\hline 2,4'-DDE & 4.0 & 0.67 & 0.61 & n.d. & 0.72 & 0.84 & n.d. & n.d. & n.d. & 0.3 & 0.2 & $0.6 \pm 0.7$ & $1.1 \pm 1.3$ \\
\hline trans-Chlordan & n.d. & 1.8 & n.d. & n.d. & n.d. & n.d. & 0.7 & 0.3 & 0.3 & 0.3 & 0.4 & $0.2 \pm 0.1$ & $0.4 \pm 0.3$ \\
\hline cis-Chlordan & n.d. & n.d. & n.d. & n.d. & n.d. & n.d. & n.d. & n.d. & n.d. & n.d. & n.d. & $0.2 \pm 0.1$ & $0.4 \pm 0.3$ \\
\hline oxy-Chlordan & n.d. & n.d. & n.d. & n.d. & n.d. & n.d. & n.d. & n.d. & 0.4 & 0.4 & 0.3 & $1.0 \pm 1.4$ & $1.9 \pm 2.9$ \\
\hline Heptachlor & n.d. & n.d. & n.d. & n.d. & n.d. & n.d. & n.d. & n.d. & n.d. & n.d. & n.d. & $0.5 \pm 0.6$ & $0.9 \pm 1.2$ \\
\hline cis-Heptachlorepoxid & 10.9 & 9.7 & 2.2 & 23 & 11.2 & 1.5 & 1.3 & 1.6 & 1.5 & 1.4 & 1.3 & $0.4 \pm 0.6$ & $0.8 \pm 1.2$ \\
\hline trans-Heptachlorepoxid & n.d. & n.d. & n.d. & n.d. & n.d. & n.d. & n.d. & n.d. & n.d. & n.d. & n.d. & $1.5 \pm 2.2$ & $3.0 \pm 4.4$ \\
\hline Aldrin & n.d. & n.d. & n.d. & n.d. & n.d. & n.d. & n.d. & n.d. & n.d. & 0.2 & 0.2 & $0.9 \pm 1.3$ & $1.8 \pm 2.6$ \\
\hline Dieldrin & 8.5 & 27 & 3.9 & 18 & 25.2 & 6.4 & 5.7 & 8.1 & 7.0 & 4.7 & 4.2 & $1.0 \pm 1.0$ & $2.0 \pm 2.0$ \\
\hline Endrin & n.d. & n.d. & n.d. & n.d. & n.d. & n.d. & n.d. & n.d. & n.d. & n.d. & n.d. & $2.6 \pm 2.4$ & $5.1 \pm 4.8$ \\
\hline Endosulfan-I & 74.5 & 34.3 & 101.0 & 89.9 & 33.9 & 116 & 15.3 & 22.4 & 17.8 & 19.5 & 16 & $2.2 \pm 2.6$ & $4.5 \pm 5.3$ \\
\hline Endosulfan-II & 139.0 & 39.6 & 132.0 & 83.9 & 61.8 & 148 & 35.5 & 37.0 & 27.4 & 33.2 & 24.9 & $2.1 \pm 2.0$ & $4.2 \pm 3.9$ \\
\hline Methoxychlor & n.d. & 0.82 & n.d. & n.d. & 1.4 & n.d. & 0.4 & 0.3 & 0.5 & 0.6 & 0.5 & $0.8 \pm 0.5$ & $1.6 \pm 1.0$ \\
\hline Mirex & n.d. & n.d. & 1.4 & n.d. & n.d. & n.d. & n.d. & n.d. & n.d. & n.d. & n.d. & $0.2 \pm 0.2$ & $1.5 \pm 0.3$ \\
\hline
\end{tabular}

fw: fresh weight; n.d.: not detectable; STD: standard deviation; Mf: "starting" infant formulae of milk-based; Sf: "starting" infant formulae of soy-based; HAf: "starting" infant formulae of hypoallergenic-based; fMf: "follow on" infant formulae of milk-based; fSf: "follow on" infant formulae soy-based; fHAf: "follow on" infant formulae hypoallergenic-based; BFB5-BFB6-BFB7-BFB8-BFB9: baby foods and beverages available for month 5, 6, 7, 8, and 9 respectively 
Table 4. The amount of the total effective xenoestrogen burden (TEXB) of baby food extracts in EScreen bioassay

\begin{tabular}{lc}
\hline & $\begin{array}{c}\text { TEXB } \\
(\mathrm{pM} \text { Eeq/g of sample) }\end{array}$ \\
\hline Mf & $0.25 \pm 0.11$ \\
HAf & $0.44 \pm 0.22$ \\
Sf & $70.13 \pm 9.81$ \\
fMf+ BFB5 & $0.22 \pm 0.15$ \\
fHAf+ BFB5 & $0.31 \pm 0.18$ \\
fSf+ BFB5 & $73.60 \pm 6.22$ \\
fMf+ BFB9 & $0.29 \pm 0.15$ \\
fHAf+ BFB9 & $0.85 \pm 0.31$ \\
fSf+ BFB9 & $69.25 \pm 8.21$ \\
\hline
\end{tabular}

Mf: "starting" infant formulae of milk-based; Sf: "starting" infant formulae of soy-based; HAf: "starting" infant formulae of hypoallergenic-based; fMf: "follow on" infant formulae of milk-based; fSf: "follow on" infant formulae soy-based; fHAf: "follow on" infant formulae hypoallergenic-based; BFB5 and BFB9: baby foods and beverages available for month 5 and 9 , respectively 
Table 5: Estimated dietary exposure to PCDD/F and PCB (pg WHO-TEQ/ kg bw/day) for non-breasted infants 0-9 months of age fed with baby foods available on the EU market

\begin{tabular}{|c|c|c|c|c|c|c|c|c|c|}
\hline \multirow{2}{*}{ Type baby foods } & \multicolumn{9}{|c|}{ Infant age (month) } \\
\hline & $0-1$ & $1-2$ & $2-3$ & $3-4$ & $4-5$ & $5-6$ & $6-7$ & $7-8$ & $8-9$ \\
\hline & \multicolumn{9}{|c|}{ PCDD/F TEQ (pg/kg bw)/day } \\
\hline Milk infant formula & 1.00 & 0.92 & 0.84 & 0.73 & 0.51 & 0.32 & 0.18 & 0.18 & 0.17 \\
\hline Soy infant formula & 1.26 & 1.15 & 1.05 & 0.91 & 0.26 & 0.16 & 0.09 & 0.09 & 0.09 \\
\hline Hypoallergenic infant formula & 2.78 & 2.52 & 2.31 & 2.01 & 0.13 & 0.08 & 0.05 & 0.04 & 0.04 \\
\hline \multirow[t]{2}{*}{ Baby foods and beverages } & & & & & 0.00 & 0.19 & 0.00 & 0.00 & 0.04 \\
\hline & \multicolumn{9}{|c|}{ PCB TEQ (pg/kg bw)/day } \\
\hline Milk infant formula & 0.03 & 0.02 & 0.02 & 0.02 & 0.04 & 0.02 & 0.01 & 0.01 & 0.01 \\
\hline Soy infant formula & 0.01 & 0.01 & 0.01 & 0.01 & 0.00 & 0.00 & 0.00 & 0.00 & 0.00 \\
\hline Hypoallergenic infant formula & 0.01 & 0.01 & 0.01 & 0.01 & 0.01 & 0.00 & 0.00 & 0.00 & 0.00 \\
\hline \multirow[t]{2}{*}{ Baby foods and beverages } & & & & & 0.00 & 0.55 & 0.73 & 0.70 & 0.72 \\
\hline & \multicolumn{9}{|c|}{ Total TEQ (pg/kg bw)/day } \\
\hline Milk infant formula & 1.03 & 0.94 & 0.86 & 0.75 & 0.55 & 1.08 & 0.92 & 0.89 & 0.94 \\
\hline Soy infant formula & 1.27 & 1.16 & 1.06 & 0.92 & 0.26 & 0.90 & 0.82 & 0.79 & 0.85 \\
\hline Hypoallergenic infant formula & 2.79 & 2.53 & 2.32 & 2.02 & 0.14 & 0.82 & 0.78 & 0.74 & 0.80 \\
\hline
\end{tabular}

